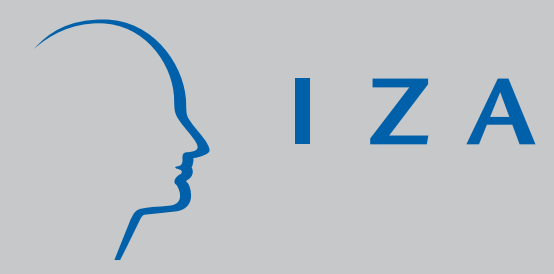

IZA DP No. 4100

Reforming German Labor Market Institutions: A Dual Path to Flexibility

Werner Eichhorst

Paul Marx

March 2009 


\title{
Reforming German Labor Market Institutions: A Dual Path to Flexibility
}

Werner Eichhorst

$I Z A$

Paul Marx

$I Z A$

\section{Discussion Paper No. 4100 \\ March 2009}

\author{
IZA \\ P.O. Box 7240 \\ 53072 Bonn \\ Germany \\ Phone: +49-228-3894-0 \\ Fax: +49-228-3894-180 \\ E-mail: iza@iza.org
}

\begin{abstract}
Any opinions expressed here are those of the author(s) and not those of IZA. Research published in this series may include views on policy, but the institute itself takes no institutional policy positions.

The Institute for the Study of Labor (IZA) in Bonn is a local and virtual international research center and a place of communication between science, politics and business. IZA is an independent nonprofit organization supported by Deutsche Post Foundation. The center is associated with the University of Bonn and offers a stimulating research environment through its international network, workshops and conferences, data service, project support, research visits and doctoral program. IZA engages in (i) original and internationally competitive research in all fields of labor economics, (ii) development of policy concepts, and (iii) dissemination of research results and concepts to the interested public.
\end{abstract}

IZA Discussion Papers often represent preliminary work and are circulated to encourage discussion. Citation of such a paper should account for its provisional character. A revised version may be available directly from the author. 


\title{
ABSTRACT
}

\section{Reforming German Labor Market Institutions: A Dual Path to Flexibility}

\begin{abstract}
Germany has always been one of the prime examples of institutional complementarities between social insurance, a rather passive welfare state, strong employment protection and collective bargaining that stabilize diversified quality production. This institutional arrangement was criticized for being the main cause of inferior labor market performance and increasing fiscal pressure on the welfare state while at the same time inhibiting institutional change. However, over the last 15 years, a sequence of institutional reforms has fundamentally modified the functioning of the German labor market and increased both flexibility and job creation capacities through two intimately linked processes that redefined the line between inactivity, the flexible and the standard segment of the labor market. On the one hand, policy changes facilitated the expansion of flexible or 'atypical' jobs, whereas increasing flexibility of the standard employment relationship resulted from wage moderation and working time flexibility. While at the outset of this reform sequence German had a small, but relatively egalitarian labor market, the number of jobs, but also their diversity has increased.
\end{abstract}

JEL Classification: J38, J51, J41

Keywords: Germany, labor market reforms, atypical employment, standard employment relationship

Corresponding author:

Werner Eichhorst

IZA

P.O. Box 7240

D-53072 Bonn

Germany

E-mail: eichhorst@iza.org 


\section{Introduction}

Throughout the 1990s, Germany was seen in line with other Continental European countries as the "sick man in Europe". Sluggish economic growth, a worsening labor market performance, apparently unsustainable social security systems, and the incapability to implement substantial reforms caused some pessimism about the future prospects of the German economic system. However, the reform activities of the past years and especially the remarkable recent employment growth made it necessary to revise the image of the Continental laggard. Germany's comeback (as well as substantial change in other Bismarckian welfare states) gave comparative labor market research something to puzzle about. After the 1990s debate was mainly about explaining inferior performance and inertia, the unexpected liberalizing tendencies of the 2000s shifted the focus towards explaining institutional change. The questions that occurred were how change does proceed in a context of path-dependent institutions and what does determine different trajectories of change. The following article shares the interest in these questions.

It is often argued that Germany followed a strategy of flexibility at the margin to modernize its labor market. In this logic of reform, the traditional institutional setting of standard employment is preserved, but supplemented with a secondary segment of 'atypical' jobs. This development can be understood as a new distribution of labor market risks: due to reform obstacles in the core of the labor market, flexibilization at the margin was seen as the only viable option. While thereby the privileges of standard employment contracts could be maintained, the price to be paid has been a growing dualization in terms of wages and employment security.

The main research questions of this paper are a) how the reform path leading to a bifurcated labor market can be explained and b) whether bifurcation constitutes a new, stable equilibrium. Concerning the latter, there is reason to doubt the pessimistic notion that change in the German labor market constitutes a one-way street to dualization. Marginal flexibilization might aim at stabilizing the overall system in the first place by decreasing reform pressure, but inevitably it also produces some repercussions for the core of the system. The paper shows that, as a reaction to the growth of non-standard jobs, employment for insiders became significantly more flexible. In contradiction to orthodox policy advice, this flexibilization did not take place by increasing external flexibility through easing dismissal protection. Rather, it was achieved by a liberalization of collective bargaining, allowing for a great deal of flexibility on the plant level in terms of 
working time and remuneration. In principle, flexibilization of standard employment should be regarded contradictory to dualization, as it increases the inclusiveness of the primary segment by lowering hiring barriers.

Analyzing interdependencies between the margin and the core has important implications for understanding institutional change in Continental European welfare states. If the reaction of insiders is taken into account, dualization can not be considered the final outcome of change, but only one stage in a longer process of renegotiating the distribution of risks and privileges between labor market segments. Following Palier and Martin's (2007) sequentialist view, it is the aim of this article to reveal a typical Continental pattern in the reform of the German employment system. The determinants of such a sequential development are various inherent barriers to change and a distinct short-term orientation, favoring incoherent or even contradictory reform stages. Moreover, we believe that the resulting trajectory leads beyond partial flexibilization - to a fundamental overhaul of the system and more inclusive standard employment.

The paper is organized as follows: at first, the traditional setting of the German labor market and its political economy are analyzed as a point of departure for labor market reform. The subsequent sections trace the reform sequences across the past 30 years and analyze their impact on the current institutional setting. In order to understand the process of dualization, each section looks at the changing flexibility of both, the core and the margin of the labor market and asks how it altered the conditions for following reforms.

\section{The German Employment Model and the Standard Employment Relation- ship ('Normalarbeitsverhältnis')}

German labor market institutions matured in the 'golden' post-war era. Although the process of establishing a modern labor market regulation and the expansion of wage labor date back to the 19th century, the pre-world war II employment contract was far from providing as much security as it does nowadays. It was only in the exceptional post-war situation with its enormous growth rates and labor shortages that the privileges of the so called 'Normalarbeitsverhältnis' (standard employment relationship) could be achieved (Mückenberger 1985, Pierenkemper 2009). The term describes a dependent, permanent full-time job with dismissal protection, full integration into status-protecting social insurance and collectively set wages significantly above the subsistence level. However, this employment system with a highly privileged group at its core required low 
labor utilization - a feature which became a heavy burden later on. With reasonable simplification one could say that classical German labor market institutions were associated with few, but only good jobs. The other side of the coin was the minor role of the service sector, in particular labor intensive personal services which were predominantly delivered as unpaid work in the family context and not via markets. The fact that inequality is not so much caused by wage dispersion, but rather by uneven access to the primary labor market, is an important difference from more flexible systems. Largely excluding women from participation and thereby reducing wage competition allowed male breadwinners to earn a sufficient family wage (Esping-Andersen 1999). For a long time during the 1980s and early 1990s, the strategy of reducing labor supply was also applied to older workers via generous early-retirement schemes. By and large, the exclusion of less productive workers made higher wages for insiders possible, but heavily burdened social insurance by financing inactivity (Hemerijck 2002). The developments, which put this system under pressure, are well known: women started to push for labor market participation (Esping-Andersen 1999, 2002) and due to demographic projections, policy makers increasingly considered more inclusive labor markets desirable. For the same reason, but especially for the costs it imposed on social insurance, the strategy of 'labor shedding' proved to be hardly sustainable (Ebbinghaus 2006). This was even more so when applied to the former GDR after reunification (Manow/Seils 2000). Finally, international competition in terms of labor costs provided attractive exit options from the expensive German system or at least improved the bargaining position for employers.

To understand why the reaction to these tendencies did not include a bold flexibilization of the 'rigid' standard employment contract, but rather aimed at creating a secondary tier with atypical jobs, one has to take into account complementarities between labor market regulation and the German manufacturing system. Streeck (1991) describes this model as "diversified quality production". In contrast to the price-competitive, Taylorist approach in Anglo-Saxon countries, its comparative advantage derives from high quality standards, a diversified product range and customization. For its superior performance, the model requires skilled labor, which in turn facilitates high productivity and high wages. As innovations typically are incremental and based upon employees' experiences with products and customer expectations, firm or industry-specific knowledge is of major importance in diversified quality production. Overcoming disincentives to invest in such specific skills (which must be considered sunk costs in case of a job loss), requires complementary labor market institutions. The corresponding type of employment is close to the 'Normalarbeitsverhältnis'. It comprises dual apprenticeships (to generate occupation-specific skills), dismissal protection (to fa- 
vor longer job duration), status-maintaining unemployment insurance (to protect skills from being depreciated in another occupation), and collective bargaining (to prevent fluctuation of wages) (Estevez-Abe/Iversen/Soskice 2001). In theory, this "high skill equilibrium" (Finegold/Soskice 1988) must be considered an obstacle to fundamental labor market reform, as a change in standard employment could undermine the foundation of the entire production model.

Additional explanations for the inertia of the core labor market derive from the political economy of Continental welfare states. Labor market and welfare reforms, which always entail short-term costs for parts of the electorate, typically are unpopular and therefore not very attractive for office-seeking policy makers (Esping-Andersen 1996, Pierson 1996, Boeri et al. 2001). This is especially true for the ideal-type Continental welfare state where contributory systems create a high legitimacy of unemployment benefits: social transfers are perceived as acquired rights rather than benevolence and so they receive high popular support. Additionally, union involvement in the administration of benefit schemes provide some veto power to advocates of the status quo (Palier/Martin 2007). A similar problem occurs with strict employment protection. Once in place, such rules create its own constituency, because they maintain workers in jobs that would have been destructed otherwise. By increasing job tenure, employment protection sets incentives to invest in firm-specific human capital. This in turn provides higher rents to job holders (due to the productivity differential compared to outsiders). As a consequence, workers who already invested in specific skills and benefit from seniority wages form an opposition towards the liberalization of dismissal laws (Saint-Paul 2002).

Hence, institutional features of Continental welfare states create a political economy much in favor of resilience. Against the backdrop of severe reform obstacles in the core of the system, piecemeal reform at the margins appears as the only viable reform strategy. By contrast, comprehensive reforms are more likely in cases where policy makers either do not face powerful veto players (Bonoli 2001, Huber/Stephens 2001) or where they can rely on an infrastructure for tripartite talks and a sufficient level of trust among the actors to negotiate social pacts (Ebbinghaus/Hassel 2000, Hassel 2003). Accordingly, the German political system with its federalism and weak tripartite coordination impedes encompassing reform strategies (Eichhorst/Konle-Seidl 2006).

These institutional features can explain the distinct reform path of Germany and other Continental welfare states. Due to the inherent hurdles for reform, the transformation proceeded in a rather fragmented way, imposing a gradual change that did not lead to direct confrontation with advocates of the status quo. 
To capture this phenomenon there has been some theorizing about incremental, but yet effective transformation in institutional contexts with low malleability. Models like "layering" (Thelen 2002), "drift" (Hacker 2003) or "conversion" (Thelen 2004) introduced the basic notion of institutional change without (or with only very modest) formal revision. It states that in some cases the process of change is composed of fractional reform steps, which (taken for themselves) only have a minor impact while their accumulated results can significantly alter the status-quo. Layering, for example, describes a process of change where a rigid institutional arrangement is supplemented by an alternative and more flexible institution at its margin. At the time of introduction, the role of this secondary institution can be insignificant, but given a process of differential growth it may crowd out the established one and therefore change the entire logic without formal revision of the initial institution (Streeck/Thelen 2005). In a similar fashion, drift occurs where the context of an institutional arrangement changes so that it does not serve its original purpose anymore. Exogenous influences like economic or societal trends usually call for some degree of adaptability. In such a case, lacking political response in terms of institutional recalibration leads to the expiration of the institution - without the necessity to achieve a political consensus for reform (Hacker 2004). Especially the mechanism of layering provides a potential explanation for the combination of institutional rigidity in the core of labor markets and exacerbated insider-outsider cleavages: if flexibilization can only be implemented at the margin (e.g. through temporary or low-wage jobs and agency work) and differential growth is promoted later on, this implies an increase in the number of atypically employed.

Following the idea of incremental change, Palier and Martin (2007) identified a typical sequential process of transformation in Continental welfare states. Starting from the adverse circumstances for institutional change, they describe a reform trajectory where each step provides for some ad-hoc adjustment to urgent problem pressure and at the same time shapes the conditions for subsequent steps. Different from fundamental reform, a short-term perspective in the problem solution prevails with the result that reform stages can even be contradictory. As Clegg (2007) points out, such a reform cascade can lead to dualization: in order to maintain insiders' privileges and yet improve labor market performance, the tendency of each reform stage is to target flexibilization at outsiders. Therefore, change in most Continental labor markets has taken place not "in spite of attempts to preserve the status quo, but rather because of them" (p. 611). By and large, the sequentialist view describes a reform path, whose single stages are restricted to the short-term interest of maintaining the overall system. As their outcomes determine the opportunities for following reforms, a more or less 
consistent reform path may occur. The consequence of this path is a strong tendency towards flexibilization through dualization. While drift and layering usually (although not necessarily) refer to politically promoted processes, where change is pursued intentionally, the sequential-reform approach points to unintended side-effects as well. This makes the approach valuable for the investigation of our thesis, which bases on the idea that short-term orientation and sideeffects have a significant influence on reform outcomes in Germany.

\section{The 1980 and the early 1990s: Reforming the margin}

The earlier phase of the transformation of the German employment system can be located somewhat between the mid-1970s and the mid-1990s. In an increasingly difficult economic environment, provisions governing the core of the labor market such as social insurance, dismissal protection, and collective bargaining remained basically intact. Early retirement and passive labor market policies were expanded to keep open unemployment low despite cyclical and structural adjustment pressure. These instruments, which were also the major tools used to cope with economic restructuring after reunification, helped, first, stabilize the income position of core workers which were made redundant and, second, rejuvenate the staff in manufacturing.

However, in the mid-1990s the persistent weakness of the German labor market to generate additional jobs, in particular in the service sector, was increasingly perceived as a direct consequence of the established institutional arrangement and the policies implemented so far. Reducing labor supply by limiting access of women to the labor market and by extensive early retirement was not seen as a remedy anymore but rather as a problem since this was associated with low activity and increasing fiscal pressure on the welfare state in terms of raising contribution rates. Consolidation of social security and some partial deregulation of the labor market appeared on the agenda. The weak development of employment in (formal) private services was largely ascribed to either strong wage compression due to sectoral collective bargaining and implicit minimum wages set by social assistance or by the growing burden of non-wage labor costs which was seen as particularly harmful to personal, labor-intensive services (Scharpf 1997).

Keeping the core of the labor market stable and productive was only one element of the policy response in this phase. As a second tier, the foundations for subsequent growth of flexible types of employment were also laid in this period. This 
holds for the liberalization of temporary work agencies in 1972 and the permission of fixed-term contracts without valid reasons in case new staff was hired in 1985. In 1996 the maximum duration of fixed-term contracts without valid reason was raised to 24 months, while the maximum number of successive contracts was limited to four. At the same time, it was prohibited to hire employees on a fixed-term basis after having them employed on a permanent basis and dismissed within four month before the temporary hiring. Dismissal protection remained in place over the whole period with some minor exceptions. In 1996, the final phase of the Christian Democratic/Liberal coalition, the size threshold relevant for the application of dismissal protection was raised from five to ten employees and social selection criteria were defined more narrowly and allowed for the consideration of enterprise interests.

In the same period, part-time work at low weekly hours became a more and more frequently used instrument in personal and private labor-intensive services such as retail trade, hotels and restaurants or office administration where regular full- and part-time work was hampered due to high non-wage labor costs. Employers increasingly relied on so-called 'geringfügige Beschäftigung' (minor employment contracts) exploiting a legal provision that had been introduced into the German social insurance code much earlier (Müller-Schoell 2006). Minor employment contracts were originally seen as a provision to allow workers with an irregular work schedule or only a few weekly hours worked to be exempted from social insurance. Now it was perceived as a strategy to establish a low-cost segment mainly employing married women seeking for some supplementary earnings.

Social insurance, active labor market policies and employment protection were not altered for regular employees - in fact, early retirement and large scale use of active labor market policies such as direct job creation, short-time work and training courses were used to reduce labor supply and limit unemployment growth. In collective bargaining, however, new forms of flexibility were introduced. Attempts at general working time reduction were complemented and balanced with more internal flexibility, e.g. through the introduction of working time accounts. In a situation of increased global competition in quality production, wage moderation became a major issue. Concession bargaining not only meant more modest wage increases but also opening clauses allowing for enterprise-level deviations in terms of remuneration or working time. Starting with pioneering agreements in the automotive industry (for example BMW in 1988), such plant-level deviations from collective agreements became an attractive tool to improve the competitiveness of firms and sectors in critical periods. Facing the 
imminent risk of unemployment, concessions were accepted by employees and trade unions in exchange for employment stability.

\section{Limiting Labor Market Flexibility: 1998-2001}

With the change in government from the Christian-Democratic/Liberal to the Social-Democratic/Green coalition in fall 1998 in the context of an economic upswing in the late 1990s, re-regulation of atypical jobs became a major issue since opposition to the cuts in social security and employment protection implemented by the preceding coalition was a major factor explaining the 1998 shift in power. Hence, in order to prevent a further crowding out of regular employment through an expansion of non-standard jobs, i.e. marginal employment and fixedterm contracts, but also self-employment, the early phase of the Red-Green coalition was characterized by steps to expand the realm of employment covered by social insurance. In 1999 dismissal protection was restored for workers in small firms between five and ten employees. A broader definition of social criteria was reestablished. Marginal jobs were partially integrated into social protection replacing former lump sum employer taxes with employer contributions to social insurance and banned second jobs free of charges. Freelance workers who worked for only one client were defined as dependent workers and therefore integrated into social insurance. Finally, in 2001, fixed-term contracts without valid reason were restricted to initial hirings, i.e. to situations in which there had not been any employment relation between employee and employer before. More coherent activation of benefit recipients and the creation of a broader low-wage sector in services in order to generate entry opportunities for long-term unemployed or low-skilled jobseekers became a more pressing, but also contentious issue at the time. This led to the introduction of limited local activation models bringing together welfare and labor market administration as well as to the implementation of regional in-work benefit experiments. Wage flexibility and wage moderation were still a major issue, however. Over the 1990s the incorporation of opening clauses in collective agreements rose further and became a wide spread instrument to realize more flexibility for individual firms. For example, between 1993 and 1999, the number of employees in industry and construction that were covered by such a clause sharply rose from 0.6 to 6.6 millions (Rehder 2003). 


\section{The Hartz reforms and 'Agenda 2010' (2002-2005)}

While the economic boom period around the millennium was associated with stronger regulatory attempts, the downturn after 2001 paved the way for a paradigm shift in labor market and social policies as well as new deregulatory reforms. Under the impression of the increasing problem pressure, the Red-Green coalition departed from the reform path that had swept it into office and implemented several changes that even contradicted earlier actions. Having used active and passive labor market policies to accommodate for lack of labor demand after reunification, Germany now embarked on the European path towards activation more seriously. The Hartz reform package together with the controversial 'Agenda 2010' meant a transition from human capital oriented labor market policies to a stronger emphasis of demanding elements reinforcing jobseekers willingness to take up even low paid jobs. This meant stricter job search monitoring, harsher sanctioning provisions in unemployment benefits and a shift from longterm training and direct job creation measures to shorter programs aiming at an accelerated reintegration into the labor market. Demanding elements become more important than in the past. The most important changes concerned unemployment benefits. After its generosity had already been affected by the removal of the qualification safeguard clause in 1997, now unemployment insurance benefit duration for older workers was shortened from 32 to 18 months. This effectively removed a de facto early retirement tool. Even more important was the merger of earnings-related, but means-tested unemployment assistance and social assistance into 'Arbeitslosengeld $\mathrm{II}^{\prime}$, a general minimum income support scheme with strong activation requirements ('Hartz IV'). In principle all jobs were considered suitable. However, the fact that minimum income support was not only available for jobseekers and unemployed persons, but was made more easily accessible for workers and self-employed with low income meant that a general in-work benefit system had been created. Given the fact that persons relying on minimum income support can earn up to 100 EUR per month without cuts in benefits and can keep 20\% of earnings between 100 and 800 EUR as well as $10 \%$ of earnings between 800 and 1200 or 1500 EUR, there are strong incentives to work part-time, in particular to combine minimum income support with a Minijob. Minijobs were also liberalized in the sense that second jobs were (again) exempted from employee social contribution and taxes. Additionally, the working time ceiling of 15 hours per week was removed. Since there is no binding minimum wage in many areas of the economy, Minijobs provide the possibility to agree on low hourly wages, which are supplemented by state subsidies. 
Besides the expansion of the Minijobs, the Red-Green government also decided to liberalize other types of atypical employment in the course of the Hartz reforms. The age threshold for the application of repeated fixed-term contracts without valid reason was lowered from 58 to 52 years. To counter legal concerns, this clause was later restricted to newly hired older unemployed. Also, newly established firms were allowed to use fixed-term contracts for up to four years without a valid reason. A similar tendency could be observed for agency work: between 1985 and 2002 the maximum duration of an assignment had been extended from three to 24 months. Only shortly after, it was finally abolished by the first Hartz law, which contained further ease of regulation. It suspended a ban on synchronization and re-employment so that agencies now can repeatedly hire a worker only for the length of his assignment in a user company. In 2003, the prohibition on agency work in construction was abolished. As agency work was seen as a promising tool to integrate unemployed into the labor market, staffing agencies were introduced into active labor market policies. Another element of flexibility implemented with the Hartz reforms and the Agenda 2010 was the strong expansion of start-up subsidies ('Me Inc.') together with an abolition of the master craftsman's diploma in many crafts.

Summarizing this phase, the reforms of second Red-Green legislative period brought about a great deal of deregulation at the margin of the labor market. But how was the core affected? Here, legislative changes were very modest. Contrary to the early years of the coalition, in 2004 the firm size threshold for dismissal protection was lifted again to ten employees. In addition, the definition of social criteria was restricted again and the consideration of business preferences introduced as further criteria. Finally, employees were allowed to opt for severance pay instead of taking legal action.

More relevant for the flexibilization of the core labor market was the advancing deterioration of collective bargaining. Besides a general trend towards lower bargaining coverage and unionization, exit options were used by more and more firms. By 2005, already 29 percent of all employees working under a collective agreement in West Germany and 21 in the east were covered by opening clauses (Kohaut/Schnabel 2007). These figures illustrate that a growing number of employees works under conditions that deviate from collectively defined ones. As the principle of favorability is avoided, the deviation is likely to be at the expense of workers, which in turn provides more flexibility to the employer. Besides the quantitative expansion, one can also observe a change in the purpose opening clauses serve. In the 1980s and 1990 they were mainly applied to handle exceptional crisis situations. But increasingly plant-level concessions are agreed upon 
in a preventive way, i.e. in the absence of acute problems (Seifert/Massa-Wirth 2005).

\section{Taming Market Forces (2005 - 2009)}

The Hartz and Agenda 2010 reform limited the realm of unemployment insurance and brought in higher flexibility at the margin in terms of temporary agency work, self-employment and low-pay jobs. While this may have contributed to job creation in the service sector, growing concerns of a widening wage dispersion as well as widely shared criticisms raised by alleged socially unfair effects of Hartz IV led to the loss of power of reform-oriented Social Democrats in 2005. The following Grand Coalition formed by Christian Democrats and Social Democrats took a much more cautious stance on labor market reforms. Shifting the regular statutory retirement age from 65 to 67 years for younger cohorts was the last retrenchment issue adopted after the Hartz reforms. Deregulatory ideas formulated in the Christian Democratic campaign, for example concerning dismissal protection, were not pursued further. On the contrary, the recent policy discourse was characterized by overwhelming equity and social justice concerns. This eventually resulted in steps aiming at restabilizing social insurance and establishing new minimum provisions at the lower end of the labor market where no collective agreements exist and where activation has increased the preparedness to take up low-paid jobs. First, unemployment benefits for older workers were prolonged from 18 to 24 months again. Second, new instruments providing subsidized employment for hard-to-place long-term unemployed were introduced, thus easing wage pressures in this segment. Finally, and most importantly, minimum wages become a prominent issue on the German policy agenda for the first time. Increases in the share of low-pay in particular in private services, most specifically the combination of low wages with in-work benefits, raised broad concerns about unfair remuneration. Trade unions and Social Democrats pushed for general statutory minimum wage, but as this was opposed by the Christian Democrats a compromise could only be reached regarding the extension of sectoral minimum wage agreements in some service sectors such as cleaning, postal services and - eventually - temporary agency work where different competing collectively agreed wage scales coexist so far.

With respect to the most recent economic downturn, German policy makers currently rely on an expansive use of short-time work or partial unemployment. The maximum duration of short-time work allowance funded by unemployment insurance was extended from 6 to 18 months for 2009 and 2010. Hence, reduced 
working hours are compensated for by social insurance if intra-firm working time flexibility is not sufficient, thus avoiding or at least postponing dismissals and loss of skilled labor. Short-time work is concentrated among export-oriented manufacturing firms which are most heavily hit by declining orders. Parallel to that, manufacturing firms have reduced the utilization of temporary agency work. In principle, agency employees also have become eligible for the shorttime work allowance, but access is more difficult for them. Hence, labor market risks of the current crisis are allocated in a dual manner: core staff is held quite stable whereas the flexible segment reacts more swiftly.

The bottom line of the previous chapters is that reforms in the German labor market proceeded in an incremental and inconsistent way. Far-reaching reform efforts usually led to electoral defeat and at least to partial re-regulation. While under these conditions privileges of standard employment (such as dismissal protection) were difficult to attack, reforms mainly addressed the (de)regulation of atypical jobs. Before an attempt is made to give an explanation for the peculiar German reform trajectory, the next chapter will present its labor market outcomes.

\section{The German Labor Market Today}

After a sequence of institutional reforms the performance of the German labor market is fundamentally different from the often stylized 'welfare without work' situation observed in the 1990s. Due to a positive interaction between dynamic economic activity and increased labor market flexibility both in the core and at the margin, total employment could reach a new peak in 2008 - just before the current economic crisis. With 69 percent, the German employment rate is now about three percentage points higher than in the last economic upturn. One has to be aware, however, the development of total hours worked was more stagnant than employment counted in persons. This is largely due to the strong expansion of part-time work. The peak of the employment rate was associated with a relatively steep decline both in registered unemployment and broad unemployment including participant stocks in active labor market policies and different nonactivating benefit schemes such as disability benefits or early retirement. Hence, the German labor market has grown - but at the same time the heterogeneity of jobs and remuneration has increased. While the share of atypical jobs rose at the expense of standard employment over the 1990s, the most recent years saw a relative stability of the numbers and shares of standard jobs. Nonetheless, flexible employment contracts such as temporary agency work, fixed-term contracts, 
marginal jobs and self employment continued to expand and offered new opportunities in the service sector for labor market entrants who had been unemployed or inactive before. Hence, after a rather strong decline in the 1990s one can currently observe some revival of standard employment relationships and socially insured jobs, accompanied by shrinking inactivity (figure 1). However, standards jobs are more flexible themselves due to flexible working time and remuneration arrangements - and long-term wage moderation has made them cheaper and more attractive to employers.

Figure 1: Employment by type of job, unemployment and inactivity, 1992-2007

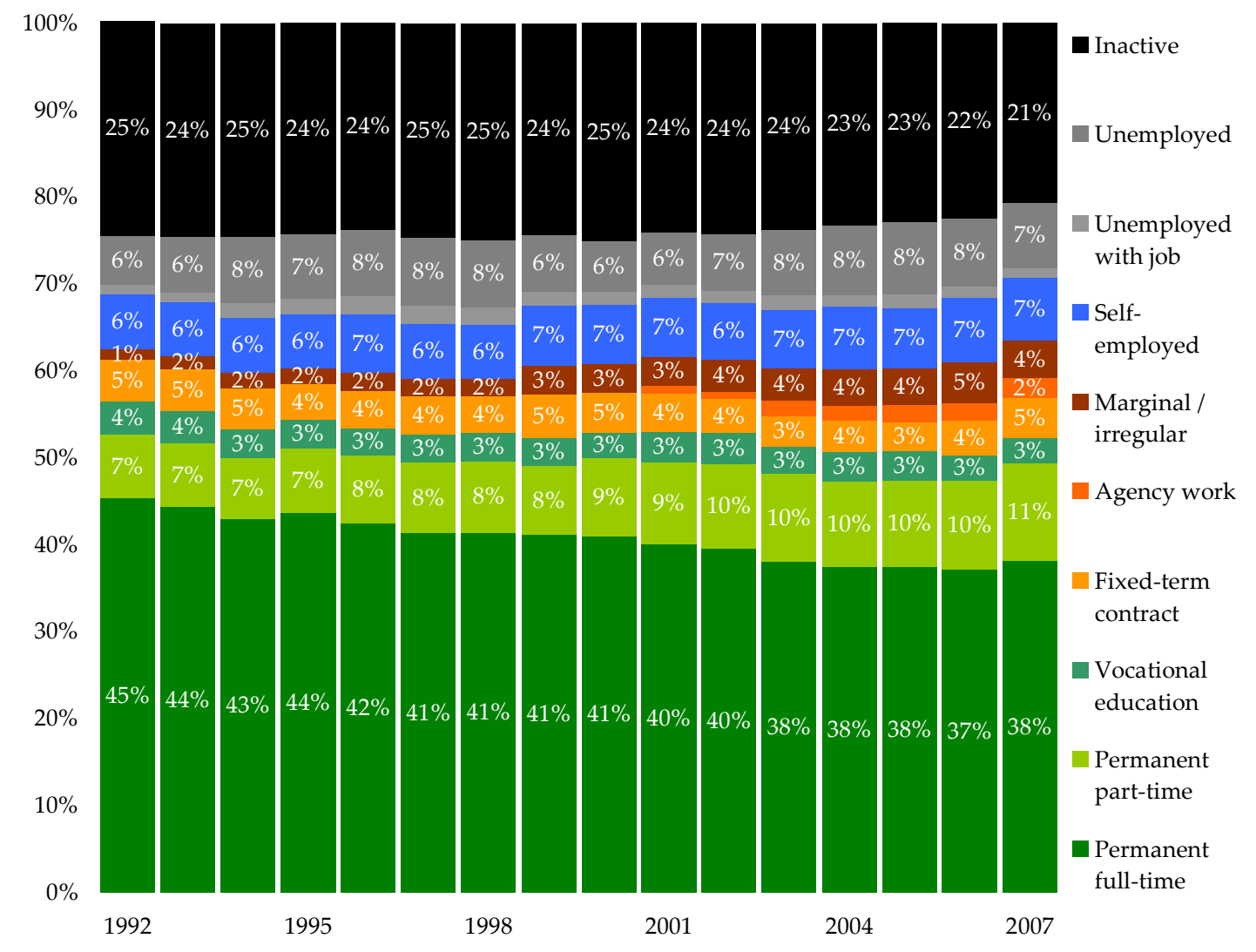

Source: GSOEP, authors' calculation.

This employment growth was associated with different forms of dualization between manufacturing and established sectors of the service economy on the one hand and dynamic private, personal and business services and creative sectors on the other hand. At the same time, new and varying forms of dualization within the sectors have emerged. First, one has to note that the share of standard employment (including longer part-time covered by social insurance) differs widely across sectors. It is much higher in traditional core sectors of manufactur- 
ing and services such as construction, energy and water supply than in public, personal and business services. Sectors which already had a low share of standard employment in the late 1990s experienced the most significant declines over the last decade while those sectors exhibiting a large share of open-ended fulltime jobs continued to do so as table 2 shows. Hence, there is a tendency of dualization with persistently high shares of standard jobs in some sectors and more diverse staffing structures in others. According to the OECD, employment stability, expressed in long average job duration did not decrease, but increase in Germany between 1992 and 2007 (from 10.7 to 11.2 years). This is in line with the observation that many firms applied a strategy of internal flexibilization. A typical pattern, especially in large manufacturing companies, is the combination of a stable core workforce with flexible working-time arrangements and the use of temporary agency work for production peaks or as a second tier of workers. However, this does not hold true for the entire economy: while business-related services are somewhat similarly organized to manufacturing (albeit with more temporary contracts and less agency work), in personal services, where the highskill equilibrium does not apply, 'hiring and firing' practices are more common (Hohendanner/Bellmann 2006).

Figure 2: Marginal employment (Minijobs) relative to employment covered by social insurance by sector, March $2008(100 \%=$ parity $)$

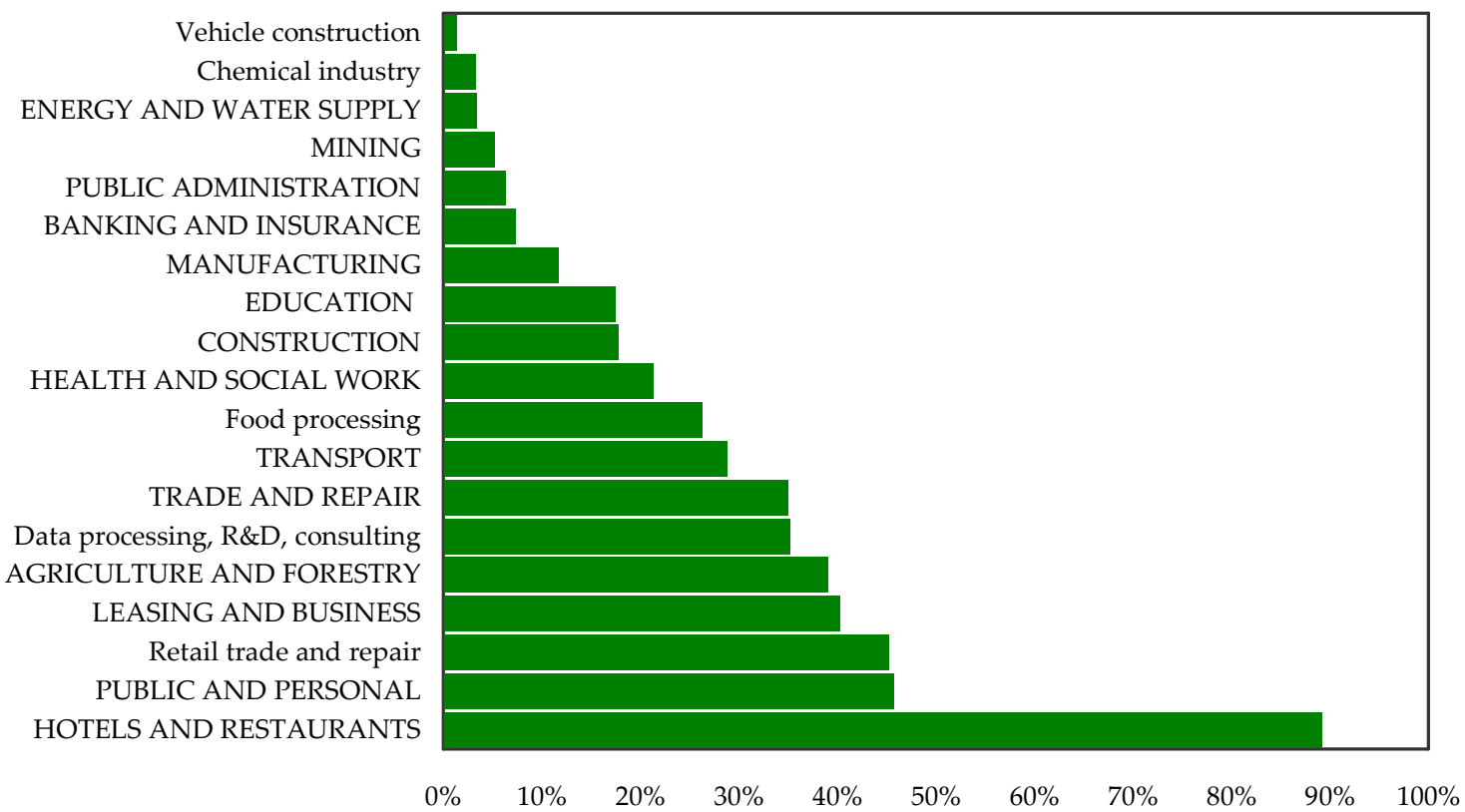

Note: Broad sectors in capital letters, other items are selected subsectors.

Source: Federal Employment Agency. 
Table 2: Standard employment relationships by sector, 1997 and 2007

\begin{tabular}{|l|c|c|c|}
\hline & $\mathbf{1 9 9 7}$ & $\mathbf{2 0 0 7}$ & Difference \\
\hline Energy and water supply & 93.1 & 90.5 & -2.6 \\
\hline Construction & 90.6 & 84.1 & -6.5 \\
\hline Manufacturing & 90.0 & 84.1 & -5.9 \\
\hline Transport and telecommunication & 88.5 & 80.7 & -7.8 \\
\hline Banking and insurance & 86.4 & 83.5 & -2.9 \\
\hline Public administration & 83.0 & 83.1 & +0.1 \\
\hline Wholesale and retail trade, repair, hotels and restaurants & 78.0 & 67.0 & -9.0 \\
\hline Agriculture, forestry and fishing & 75.3 & 70.6 & -4.7 \\
\hline Real estate, business services & 75.0 & 66.0 & -9.0 \\
\hline Public and personal services & 72.1 & 64.0 & -8.1 \\
\hline
\end{tabular}

Note: Standard employment relationships comprise both full-time open-ended contracts and part-time work of more than 20 hours per week; source: Mikrozensus.

The profile of sectors with respect to the use of different forms of non-standard employment is also diverse (table 3). High shares of employment covered by social insurance are found in manufacturing whereas less than $60 \%$ fall in this category in restaurants, cleaning and other services. Longer part-time work (which is integrated into social insurance) makes up more than one third of all employees in the latter sector as well as in health, education and social services. Together with business and distributional services these sectors also have larger shares of Minijobs, while fixed-term jobs are mostly found in education, health and other social services. In cultural and creative sectors, but also in IT, self-employment features prominently.

Table 3: Types of jobs in major sectors in \% of total sectoral employment, 2006

\begin{tabular}{|l|c|c|c|c|c|c|c|c|}
\hline & $\begin{array}{c}\text { Covered } \\
\text { by social } \\
\text { insurance }\end{array}$ & $\begin{array}{c}\text { Part- } \\
\text { time }\end{array}$ & $\begin{array}{c}\text { Mini- } \\
\text { jobs }\end{array}$ & $\begin{array}{c}\text { Fixed- } \\
\text { term }\end{array}$ & $\begin{array}{c}\text { Free- } \\
\text { lance }\end{array}$ & Interns & $\begin{array}{c}\text { Agency } \\
\text { work }\end{array}$ & $\begin{array}{c}\text { One } \\
\text { Euro } \\
\text { Jobs }\end{array}$ \\
\hline Manufacturing & 84 & 11 & 6 & 4 & 1 & 1 & 3 & 0 \\
\hline $\begin{array}{l}\text { Business and financial } \\
\text { services }\end{array}$ & 74 & 26 & 13 & 7 & 4 & 2 & 1 & 0 \\
\hline $\begin{array}{l}\text { Retail, repair, transport, } \\
\text { telecommunication }\end{array}$ & 74 & 28 & 15 & 4 & 1 & 2 & 1 & 0 \\
\hline $\begin{array}{l}\text { Health, education, } \\
\text { social services }\end{array}$ & 72 & 41 & 11 & 12 & 3 & 3 & 0 & 4 \\
\hline Public administration & 63 & 27 & 3 & 6 & 1 & 1 & 0 & 3 \\
\hline $\begin{array}{l}\text { Restaurants, cleaning, } \\
\text { other personal services }\end{array}$ & 57 & 37 & 26 & 8 & 3 & 2 & 0 & 2 \\
\hline
\end{tabular}

Source: IAB Establishment panel, Bellmann/Fischer/Hohendanner 2009. 
Temporary agency work now is a second tier of employment in manufacturing, particularly in metalworking and vehicle construction. It owes its attractiveness not only to greater numerical flexibility, as might be expected, but largely to the possibility to avoid higher wages. Due to the effects of the Hartz legislation (which will be discussed in detail in the next chapter) there are possibilities for virtually unlimited assignments of agency workers at a collectively agreed wage significantly below the wage scale of the metal sector. Given this option, production staff that is mainly unskilled or low-skilled (table 4), can effectively be employed at different wage levels for similar tasks.

Table 4: Occupations with more than five percent of agency workers, 2007

\begin{tabular}{|l|c|}
\hline \multicolumn{1}{|c|}{ Occupation } & $\begin{array}{c}\text { Share of agency workers in all workers } \\
\text { covered by social insurance in \% }\end{array}$ \\
\hline Unskilled laborers without further specification & 41.5 \\
\hline Welders & 12.9 \\
\hline Forklift operators & 11.3 \\
\hline Warehousemen, transport operators & 10.1 \\
\hline Painters and varnishers & 6.8 \\
\hline Metalworkers & 6.8 \\
\hline Promotional specialists & 6.0 \\
\hline Electricians & 5.9 \\
\hline Data entry operators & 5.9 \\
\hline Telephone operators & 5.4 \\
\hline Pipe layers and jointers & 5.3 \\
\hline
\end{tabular}

Source: Brenke/Eichhorst 2008.

Table 5: Full-time employees depending on basic income support, 2005

\begin{tabular}{|l|c|c|}
\hline & $\begin{array}{c}\text { Full-time workers receiv- } \\
\text { ing income support }\end{array}$ & $\begin{array}{c}\text { Share of full-time work- } \\
\text { ers in the sector in \% }\end{array}$ \\
\hline Placement and temporary work agencies & 36,700 & 2.1 \\
\hline Hotels and restaurants & 23,300 & 2.6 \\
\hline Cleaning & 10,500 & 0.8 \\
\hline Agriculture & 10,400 & 1.2 \\
\hline Transport & 10,100 & 1.6 \\
\hline Social services & 11,500 & 2.9 \\
\hline Construction & 9,400 & 3.1 \\
\hline Health & 9,000 & 6.4 \\
\hline \hline
\end{tabular}

Source: Bruckmeier/Graf/Rudolph 2007. 
In more labor-intensive and less skills-oriented service sectors, agency work is more frequent as are Minijobs (which are often held by married workers or by benefit recipients). As table 5 shows, in some cases even full-time employees rely on in-work benefits provided by the minimum income support scheme.

By and large, a growing heterogeneity concerning employment contracts can be observed. This also holds true with respect to wage dispersion. The share of low wage grew strongly over the last decade as did wage dispersion among full-time workers (figure 3).

Figure 3: Wage dispersion of full-time workers, 1996 and 2006

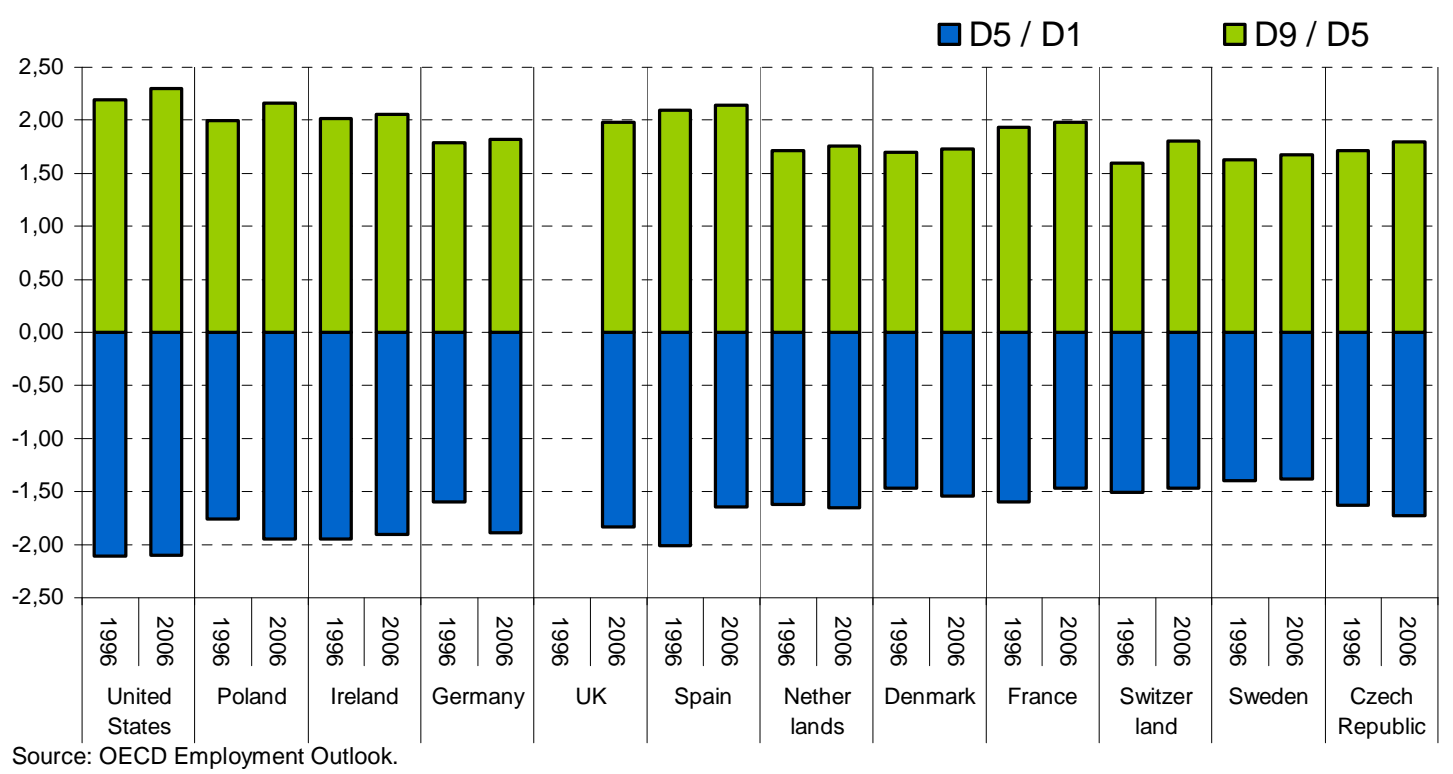

However, low hourly wages are mostly found amongst part-time workers, Minijob holders and working unemployed, i.e. in cases where employees can rely on other sources of income such as spouse's earnings or in-work benefits. Hence, intra-household or public income support allowed for the emergence of a sector of low wage employment which, in turn, works as a marginal, more implicit and somewhat unintended second best solution to the German labor cost problem in some labor-intensive services (table 6).

Dualization is not only a feature that can be observed when looking at overall or sectoral stocks of atypical or low-wage jobs. Even more crucial are patterns of persistence and chances of transition to more sustainable employment. Again, the extent to which atypical and low-wage jobs provide stepping stones or dead ends varies across the type of job. It also depends on sectoral and personal characteristics. With reasonable simplification one can say that, in contrast to many 
other Continental European countries, fixed-term contracts often provide effective entry opportunities as they are used during qualification phases, mainly in the public sector, or as extended probationary periods in particular in industry and private services (Boockmann/Hagen 2006). Repeated spells of fixed-term contracts are less common except for research, cultural and social services (table 7).

Table 6: Workers earning less than 7.50 € per hour gross, 2006

\begin{tabular}{|l|c|c|c|c|c|c|}
\hline \multirow{2}{*}{} & \multicolumn{2}{|c|}{ Germany } & \multicolumn{2}{c|}{ West Germany } & \multicolumn{2}{c|}{ East Germany } \\
\cline { 2 - 7 } & In \% & $\begin{array}{c}\text { Number } \\
\text { in 1,000s }\end{array}$ & In \% & $\begin{array}{c}\text { Number } \\
\text { in 1,000s }\end{array}$ & In \% & $\begin{array}{c}\text { Number } \\
\text { in 1,000s }\end{array}$ \\
\hline Full-time & 7 & 1,390 & 5 & 840 & 16 & 520 \\
\hline Part-time & 11 & 540 & 9 & 360 & 20 & 170 \\
\hline Mini and Midijobs & 42 & 940 & 42 & 880 & 41 & 50 \\
\hline $\begin{array}{l}\text { Working pensioners, } \\
\text { students, unem- } \\
\text { ployed }\end{array}$ & 50 & 930 & 45 & 610 & 64 & 250 \\
\hline Total & 12 & 3,720 & 11 & 2,660 & 21 & 980 \\
\hline
\end{tabular}

Source: Brenke/Ziemendorff 2008.

The potential of upward mobility is more limited with regard to Minijobs. There are strong disincentives to move to longer part-time or even full-time work due to the rapid phase in of taxation and social insurance contributions above the 400 EUR threshold, with the effect that Minijobs tend to be rather persistent (Fertig/Kluve 2006, Freier/Steiner 2008). Agency work was mainly furthered to provide a way to integrate the unemployed into the labor market. In fact, statistical data confirm that agency workers were often unemployed before taking up an agency job. But empirical studies could not provide evidence that temporary agency work is a superior stepping stone so far (Kvasnicka 2008). This may even be more doubtful in cases of long-term posting in manufacturing where agency work is rather used as a stable secondary tier of employment substituting for direct hirings. In contrast, subsidized start-ups proved to be relatively stable as an alternative to unemployment as well as an instrument to further job creation (Caliendo/Künn/Wiesner 2008). Persistence is more of a problem in the low-wage sector where upward mobility seems quite limited in Germany and probably lower than in the past (Schank et al. 2008). Low-skilled and older workers find it particularly hard to move to higher remuneration - as do part-time workers and Minijob holders. The same is true for the persistence of combinations of low earnings and minimum income support. Exit from benefit receipt is more fre- 
quent in case of full-time workers than for those who work only within the range of 400 EUR (Bruckmeier/Graf/Rudolph 2007).

Table 7: Role of fixed-term contracts and transition rates by sector

\begin{tabular}{|l|c|c|c|c|}
\hline & $\begin{array}{c}\text { Share of } \\
\text { fixed-term } \\
\text { contracts in } \\
\text { \% of total } \\
\text { employment } \\
\text { in sector }\end{array}$ & $\begin{array}{c}\text { Share of } \\
\text { fixed-term } \\
\text { contracts in } \\
\text { \% of new } \\
\text { hirings }\end{array}$ & $\begin{array}{c}\text { Transition rate to } \\
\text { open-ended con- } \\
\text { tracts in \% of all } \\
\text { terminations of } \\
\text { fixed-term con- } \\
\text { tracts }\end{array}$ & $\begin{array}{c}\text { Termination of } \\
\text { employment by } \\
\text { expiry of fixed- } \\
\text { term contracts in } \\
\text { \% of all termina- } \\
\text { tions }\end{array}$ \\
\hline Manufacturing & 4 & 40 & 59 & 17 \\
\hline Business and financial services & 7 & 37 & 48 & 12 \\
\hline $\begin{array}{l}\text { Retail, repair, transport, tele- } \\
\text { communication }\end{array}$ & 4 & 35 & 62 & 8 \\
\hline $\begin{array}{l}\text { Restaurants, cleaning, other } \\
\text { personal services }\end{array}$ & 8 & 38 & 40 & 14 \\
\hline $\begin{array}{l}\text { Health, education, social ser- } \\
\text { vices }\end{array}$ & 12 & 64 & 31 & 34 \\
\hline Public administration & 6 & 67 & 24 & 36 \\
\hline
\end{tabular}

Source: Establishment panel, Bellmann/Fischer/Hohendanner 2009.

\section{A Dualized Pattern of Flexibility}

Turning back to the initial question of this paper, first of all, it can be concluded that the German labor market does exemplify a process of incremental change. As could be shown by the description of reforms over the last two decades, a sequence of interwoven changes in public policy and collective bargaining has contributed to a broad transformation of the German labor market. On the one hand, changes in employment protection led to a redefinition of the margin by setting up alternative employment types while dismissal protection of standard employment was hardly modified. On the other hand, the shift towards activation meant stricter limitations to status-oriented social protection and increased job search requirement, however, mostly for the long-term unemployed.

All these provisions subsumed under the heading of 'marginal flexibilization' were launched with small, at first glance negligible reforms, but over time became major elements of the institutional set-up. For instance, atypical types of employment like agency work and temporary contracts have been introduced as marginal supplements in the beginning, but through an incremental process of 
differential growth they gained significance in the German labor market. Against this backdrop, large parts of German labor market reforms can be, at least with hindsight, perceived in terms of layering. However, the partial crowding-out of standard employment can not be merely understood as a politically intended process. In accordance with the assumptions made in the beginning of this paper, it seems that policy makers did not pursue a deliberate long-term strategy, but that they were guided by a) the motivation to preserve the status-quo as far as possible and $b$ ) a short-term perspective on acute problems. Both features result from the political economy of Continental welfare states (which becomes visible in the German electorates' reaction on more ambitious reforms) and help to explain the peculiar evolution of the German system.

To understand the contradictory reform trajectory in the German labor market, one has to take into consideration that the question of how to regulate atypical work places policy makers in a strategic dilemma: such jobs stabilize the core by making the system more efficient, but at the same time they tend to replace regular employment. This dilemma can be illustrated by the position of unions and works councils towards the issue. Since the introduction of agency work in the 1970s, unions heavily opposed it and collective agreements with temporary-work agencies were objected. The intention was to prevent crowding-out of standard jobs and to achieve a total ban on agency work. However, many works councils in user companies followed a different rationale. In the German dual system of industrial relations, plant-level codetermination is formally independent from unions. Therefore, works councils were free to agree on plant-level compromises, in which acceptance of agency work was traded against maintenance of core workforce privileges. By increasing numerical flexibility, agency work also was seen as a means to secure standard jobs (Holst et al. 2008, Promberger 2005). Hence, in the course of the 1990s, unions partly gave up their strict attitude towards agency work. This was mainly due to persistent mass unemployment, which questioned the legitimacy of union strategies and brought about strong pressure to achieve more flexibility in the labor market. In fact, the reorientation went so far that the umbrella organization of German unions, which was involved in the Hartz reforms, did approve the liberalization of agency work in 2004. The purpose of the reform was to increase the numerical flexibility of firms and to create more employment. To prevent wage competition between atypical and standard jobs, the principle of equal pay was agreed upon. The exception from this principle (for cases where agency workers have their own collective agreement) was not considered problematic, as it gave unions for the first time control over agency workers' wages. However, the clause was used by employers and so called 'Christian unions' (which are way closer to employers' interests 
than the majority unions) to agree on very low wages for agency workers. This avoidance of equal treatment was neither expected by the government nor by unions and led to a considerable wage gap. Accordingly, agency work largely owes its attractiveness to an unintended wage competition. It is only lately that the Grand Coalition government of Christian and Social Democrats, who introduced the reforms in 2003/04, decided to re-regulate agency work with minimum wages. This will mean a partial closure of the wage gap resulting from the former reform. But the fact that there are competing minimum wage proposals in the agency sector makes a solution particularly difficult.

The example of agency work reveals typical features of German labor market reform: changes aimed at stabilizing the overall system of standard employment in a short-term perspective may lead to more fundamental change in the long run. Although one can reasonably argue that the reform trajectory followed the mechanism of layering, no long-term strategy to promote differential growth is recognizable. Over the last decades, reforms were implemented by Conservatives as well as Social Democrats. And the largest expansion of agency work even appears to be due to unintended side-effects which are tackled again by recent legislation.

The growth of atypical employment raises the question whether there are consequences for the institutional design of standard employment. It has been mentioned above that flexible jobs simultaneously contradict and reinforce the 'rule' of the standard employment relationship (Clegg 2007), because the dualized logic relieves reform pressure on the overall system, but, in turn, creates competition between labor market segments. In such a context, the specificity of their human capital makes the group of insiders particularly vulnerable. Limited portability of skills bears the risk of sunk costs in case of dismissal. Thus, mass unemployment and a reform agenda, which promotes the availability of cheap alternatives in the labor market, constitute a serious threat to job holders. Accordingly, one would expect an ambivalent attitude of insiders towards dualization: atypical jobs can be seen as a means to sustain privileges, but once they start to replace standard employment, pressure for reform of the core labor market even increases. However, as the German high-skill equilibrium is largely incompatible with a more dynamic labor market, this reform pressure is not likely to lead to more external flexibility, which would contradict core workers' as well as employers' interests. Rather, one would expect a reaction buttressing a long-term employment relationship, i.e. strategies aiming at more internal flexibility on the plant level (Carlin/Soskice 2009). And in fact, as expected against the backdrop of labor market complementarities, the regulation of regular dismissals has been overly stable with only minor changes. Concerning unemployment benefits, the 
Hartz reforms mainly addressed long-term recipients, while the net replacement rates within the first year remained very high by international standards (OECD 2007).

The flexibilization of the German core labor market can not be ascribed to state regulation, but has its roots in private sector compromises. Over the past twenty years, it was primarily achieved by a reinterpretation of collective bargaining institutions. In a process of "coordinated decentralization" (Bosch 2004) unions increasingly accepted the flexibilization of industry-wide agreements via opening clauses, which permit considerable firm-level deviations. Their willingness to do so is to be explained by the crisis German unions face. Traditionally, centralization on branch level and pattern-setting by the export-oriented sector allowed German unions to minimize wage competition. However, from the early 1990s onwards, the downward rigidity of wages and inflexibility of working-time arrangements were more and more perceived as excessively restrictive and led to a substantial withdrawal from collective bargaining. The crisis was exacerbated by a dramatic decline of membership in the post-unification era, which meant a further loss of bargaining power and political influence. Against this background, unions were not able to resist demands for more plant-level differentiation (Addison et al. 2007, Hassel/Rehder 2001).

Thus, although collective agreements are still in force and cover considerable parts of the labor force, the advancement of opening clauses means a shift of bargaining power within the dual system from sectoral interest representation towards works councils. As their primary concern is not so much inter-firm solidarity, but rather to prevent downsizing of the core workforce, plant-level agreements are more likely to contain productivity-oriented concessions (Whittall 2005). Given the possibility to substitute external by internal adaptability, opting for flexible working-time and wage cuts usually appears as the lesser of two evils from a works council perspective. Such arrangements constitute a functional equivalent to external flexibility (e.g. redundancies or increased use of agency work), because the volume of work can be adapted to short-term variations in the production. Altogether, the labor cost gap between standard and atypical employment decreases. The growth of firm-level agreements and working-time flexibility therefore can be interpreted as a strategic response of insiders to the threat of greater external flexibility. This notion is supported by the fact that works council agreement to flexibilization is not limited to exceptional crisis situations, where redundancies constitute an immediate threat (which is the original idea). Rather, opening clauses were increasingly taken up by 'healthy' firms as well, meaning that they became a normal tool to foster the competitiveness of standard employment (Seifert/Massa-Wirth 2005). It follows that firms 
have the possibility to impose parts of their entrepreneurial risk on their employees. In the context of coordinated decentralization, the consequences of shocks can more easily be redirected to the workforce, which (depending on the case) has to accept wage cuts or an intensified labor process and reduced leisure time.

Taking the competition between typical and atypical work into account helps to understand the profound reinterpretation of German social partnership in the past 20 years. In the decentralized system, core workers face strong pressure to trade income security against (the maintenance of) job security. It can be assumed that the tendency towards flexibility in standard employment is favored by the growing competition of atypical jobs, which constitute a cheap alternative. However, it seems that particularly in the manufacturing sector also employers prefer the combination of internal flexibilization with agency work, which allows them to retain firm-specific knowledge in periods of cyclical slumps.

Table 8: Sequences of reforms since the early nineties

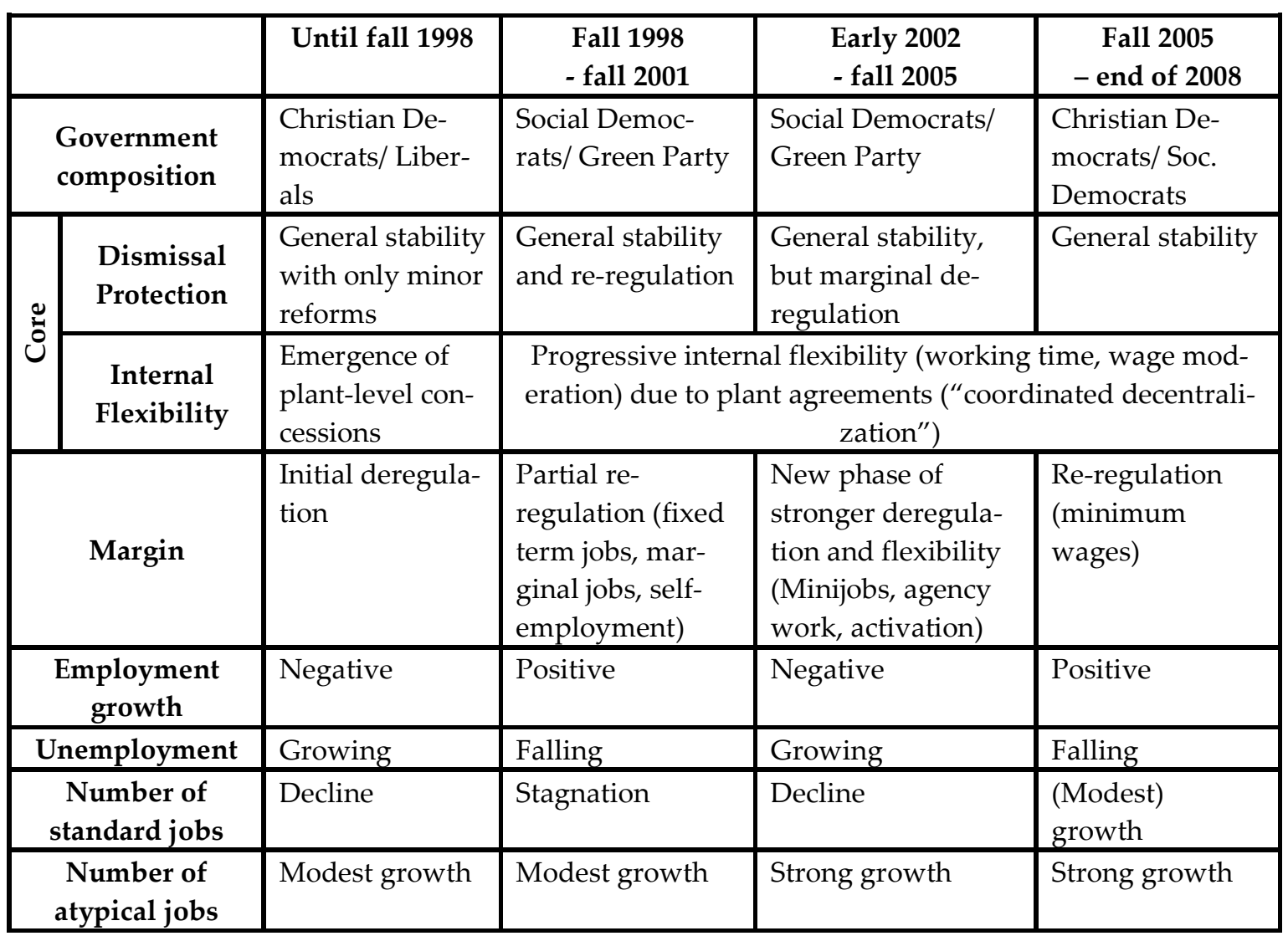

Source: authors' compilation.

Table 8 summarizes the logic of labor market reform in Germany. It reveals an inconsistent succession of deregulatory and re-regulatory phases as well as the 
mechanism behind this process: in critical periods with high adjustment pressure (expressed in negative employment growth and rising unemployment) attempts at stronger deregulation are made, while the subsequent economic pick-up usually leads to partial re-regulation. This is in line with the assumptions made about the characteristics of reform in Continental welfare states: short-term orientation, status-quo bias, and transformation through incremental change.

\section{Outlook: Dualized Flexibility and Beyond}

The German labor market exhibits a dual model of flexibility. Against the popular notion of overly rigid standard employment, it seems that both the core and the margin are flexible - but in very different ways. Standard employment is still sheltered by dismissal protection, but has changed significantly with respect to collective bargaining, wages and working time - and indirectly, flexibility at the margin inserted via temporary agency work, fixed-term contracts and marginal jobs has contributed to this. Both sides of flexibility have a competitive relationship, but they also reinforce each other. Thus, there are new forms of interaction or complementarity between core and margin in particular in manufacturing, where agency work effectively constitutes an alternative tier of a marginal labor force since, in exchange for coverage by equal pay or collective agreements, it is in principle possible to post agency workers on a permanent basis. A similar pattern can be observed in services with part-time work and Minijobs and in the public sector with fixed-term contracts.

Structural change does and probably will play a crucial role in the transformation of the German labor market. Standard employment relationships are still there, open-ended, full-time, but they are more flexible - and the recent growth of socially insured jobs can in fact be attributed to wage moderation in standard employment and a growing part of fixed-term and part-time jobs and agency work. Flexible employment seems to benefit from the growth of the service sector. Here, atypical jobs massively contributed to job creation, as it helped to overcome traditional labor cost and regulatory problems. However, job growth was associated with higher inequality between jobs. A growing low-wage sector driven by lower bargaining coverage in full-time jobs, larger numbers of parttime and marginal jobs as well as in-work benefits implicitly eased some of Germany's notorious labor cost problems in the service economy. Hence, there is a double dualization: an inter- and an intra-sectoral one. The current downturn threatens not only atypical workers, but it may also lead to a medium- and longterm decline in core manufacturing sectors and traditional services. As these sec- 
tors still show high shares of standard employment, this process will be associated with a shrinking number of regular jobs. Future job creation in services will then probably imply a stronger reliance on flexible, non-standard jobs.

With respect to the future of the German employment system, there are reasons to be more optimistic than most commentators are at the moment. For one thing, the erosion of the 'Normalarbeitsverhältnis' might be less severe than commonly depicted. Standard employment relationships are still there, open-ended, fulltime, but they are more flexible - and the recent growth of socially insured jobs can in fact be attributed to wage moderation in this segment. In sharp contrast to state regulation, social partnership has proven that it is capable to adopt standard employment to increased competitive pressure. The chosen path of internal flexibilization is compatible with the typical German production model and at the same time it provides more numerical and wage flexibility to employers. Thereby, it might not make atypical work redundant, but it certainly is a way to make standard jobs more cost attractive and to reduce the demand for alternative types of employment. Also, skilled labor will benefit from demographic change and a longer working life which may also mean stronger investment in long-term employment and lifelong learning.

Even if - driven by structural change - standard employment should continue to decline, this does not necessarily mean ever lower employment security and stronger wage dispersion. The most recent attempts at limiting market forces can be seen as part of policies emphasizing minimum income protection and minimum standards in an otherwise more flexible labor market. At the same time, social insurance has lost much of its status-protecting substance due to pension reforms, the abolition of early retirement and stronger activation. Hence, the future may bring about some erosion of the duality between status-oriented social insurance and minimum standards. The Bismarckian tradition will probably continue to exist, but it will mean less privileges compared to alternative types of employment, as minimum standards become more substantial. This would mean less dualism and a more egalitarian distribution of labor market risks. 


\section{References}

Addison, J./Schnabel, C./Wagner, J. (2007): The (Parlous) State of German Unions, Journal of Labor Research, 28(1), 3-18.

Berg, P. (2008): Working Time Flexibility in the German Employment Relation System. Implications for Germany and Lessons for the United States, Industrielle Beziehungen, 15(2), 133-150.

Boeri, T./Börsch-Supan, A./Tabellini, G. (2001): Would You Like To Shrink the Welfare State? A Survey of European Citizens, Economic Policy, 32(1), 7-50.

Bonoli, G. (2001): Political Institutions, Veto Points, and the Process of Welfare State Adaptation, in: Pierson, P. (ed.): The New Politics of the Welfare State, Oxford, 238-264.

Boockmann, B./Hagen, T. (2006): Befristete Beschäftigungsverhältnisse - Brücken in den Arbeitsmarkt oder Instrumente der Segmentierung? Baden-Baden.

Bosch, G. (2004): The Changing Nature of Collective Bargaining in Germany: Coordinated Decentralization, in: Katz, H.C./Lee, W./Lee, J. (eds.): The New Structure of Labor Relations. Tripartism and Decentralization, Ithaca, 84-118.

Brenke, K./Ziemendorff, J. (2008): Hilfebedürftig trotz Arbeit? - kein Massenphänomen in Deutschland. DIW Wochenbericht 75 (4), 33-40.

Brenke, K./Eichhorst, W. (2008): Leiharbeit breitet sich rasant aus. DIW Wochenbericht 75 (19), 244-252.

Bruckmeier, K./Graf, T./Rudolph, H. (2007): Aufstocker - bedürftig trotz Arbeit. IAB.

Caliendo, M./Künn, S./Wiesner, F. (2008): Die Nachhaltigkeit von geförderten Existenzgründungen aus der Arbeitslosigkeit. IZA Discussion Paper 3880.

Carlin, W./Soskice, D. (2009): German Economic Performance: Disentangling the Role of Supply-side Reforms, Macroeconomic Policy and Coordinated Economy Institutions, Socio-Economic Review, 2009(7), 67-99.

Clegg, D. (2007): Continental Drift: On Unemployment Policy Change in Bismarckian Welfare States, Social Policy \& Administration, 41(6), 597-617.

Ebbinghaus, B./Hassel, A. (2000): Striking Deals: Concertation in the Reform of Continental European Welfare States, Journal of European Public Policy, 7(1), 4462. 
Ebbinghaus, B. (2006): Reforming Early Retirement in Europe, Japan and the USA. Oxford.

Eichhorst, W./Konle-Seidl, R. (2006): The Interaction of Labor Market Regulation and Labor Market Policies in Welfare State Reform, Comparative Labor Law and Policy Journal, 28 (1), 1- 41.

Esping-Andersen, G. (1996): Welfare States in Transition. National Adaptations in Global Economies, London.

Esping-Andersen, G. (1999): The Social Foundations of Postindustrial Economies, Oxford.

Esping-Andersen, G. (2002): A New Gender Contract, in: Esping-Andersen, G. (ed.): Why We Need a New Welfare State, Oxford, 68-95.

Estevez-Abe, M./Iversen, T./Soskice, D. (2001): "Social Protection and the Formation of Skills: A Reinterpretation of the Welfare State," in: Hall, P.A./Soskice, D. (eds.): Varieties of Capitalism: The Institutional Foundations of Comparative Advantage, Oxford.

Fertig, M./Kluve, J. (2006): Alternative Beschäftigungsformen in Deutschland: Effekte der Neuregelung von Zeitarbeit, Minijobs und Midijobs, Vierteljahrsheft zur Wirtschaftsforschung 75 (3), 97-117.

Finegold, D./Soskice, D. (1988): The Failure of Training in Britain: Analysis and Prescription, Oxford Review of Economic Policy, 4(3), 21-51.

Freier, R./Steiner, V. (2008): 'Marginal employment': stepping stone or dead end? Evaluating the German experience, Zeitschrift für Arbeitsmarktforschung 41(23), 223-243.

Hacker, J. S. (2004): Privatizing Risk without Privatizing the Welfare State: The Hidden Politics of Social Policy Retrenchment in the United States, American Political Science Review, 98(2), 243-260.

Hassel, A. (2003): The Politics of Social Pacts, British Journal of Industrial Relations, 41 (4), 707-726.

Hassel,A./ Rehder, B. (2001): Institutional Change in the German Wage Bargaining System - The Role of Big Companies, MPIfG Working Paper 01/9, December 2001.

Hemerijk, A. (2002): The Self-Transformation of the European Social Model(s), in: Esping-Andersen, G. (ed.): Why We Need a New Welfare State, Oxford, 173-214.

Hohendanner, C./Bellmann, L. (2006): Interne und externe Flexibilität, WSIMitteilungen, 5/2006, 241-246. 
Holst, H./Aust, A./Pernicka, S. (2008): Collective representation of Interests in a Strategic Dilemma - Atypical Employees and the "Threefold Crisis" of the Labor Unions, Zeitschrift für Soziologie, 37(2), 158-176.

Huber, E./Stephens, J. D. (2001): Development and Crisis of the Welfare State: Parties and Politics in the Global Markets, Chicago.

Kohaut, S./Schnabel, C. (2007): Tarifliche Öffnungsklauseln: Verbreitung, Inanspruchnahme und Bedeutung, Sozialer Fortschritt, 56(2), 33-40.

Kvasnicka, M. (2008): Does temporary help work provide a stepping stone to regular employment? NBER Working Paper 13843, Cambridge Mass.

Manow, P./Seils, E. (2000): Adjusting Badly: The German Welfare State, Structural Change, and the Open Economy, in: Scharpf, F. W./ Schmidt, V. A. (ed.): Welfare and Work in the Open Economy. Diverse Response to Common Challenges, Oxford, 264-307.

Mückenberger, U. (1985): Die Krise des Normalarbeitsverhältnisses, Mitteilungen der Zentralen Wissenschaftlichen Einrichtung Arbeit und Betrieb 11/12, 1985, 336.

Müller-Schoell, T. (2006). Lohn oder Arbeitsplatz oder Rente? Drei Reaktionen auf das Trilemma der Sozialversicherungspflicht in konservativen Wohlfahrtsstaaten. University of Bremen.

OECD (2007): Benefits and Wages 2007. OECD Indicators, Paris.

Palier, B./Martin, C. (2007): Editorial Introduction. From 'a Frozen Landscape' to Structural Reform: The Sequential Transformation of Bismarckian Welfare Systems, Social Policy \& Administration, 41(6), 535-554.

Pierenkemper, T. (2009): The Rise and Fall of the "Normalarbeitsverhältnis" in Germany, IZA Discussion Paper 4068.

Pierson, P. (1996): The New Politics of the Welfare State, World Politics, 48(2), 143-179.

Promberger, M. (2005): Leiharbeit. Flexibilitäts- und Unsicherheitspotenziale in der betrieblichen Praxis, in: Kronauer, M./Linne, G. (ed.): Flexicurity. Die Suche nach der Sicherheit in der Flexibilität, Berlin.

Rehder, B. (2003): Betriebliche Bündnisse für Arbeit in Deutschland, Frankfurt am Main.

Saint-Paul, G. (2002): The Political Economy of Employment Protection, Journal of Political Economy, 110(3), 672-704. 
Scharpf, F. W. (1997): Employment and the Welfare State: A Continental Dilemma, MPIfG Working Paper 97/7, July 1997.

Schank, T./Schnabel, C./Stephani, J./Bender, S. (2008): Niedriglohnbeschäftigung: Sackgasse oder Chance zum Aufstieg? IAB Kurzbericht 8/2008, Nürnberg.

Seifert, H./Massa-Wirth, H. (2005): Pacts for Employment and Competitiveness in Germany, Industrial Relations Journal, 36(3), 217-240.

Streeck, W. (1991): On the Institutional Conditions of Diversified Quality Production, in: Matzner, E./Streeck, W. (eds.): Beyond Keynesianism. The SocioEconomics of Production and Employment, London, 21-61.

Streeck, W./Thelen, K. (2005): Introduction: Institutional Change in Advanced Political Economies, in: Streeck, W./ Thelen, K. (eds.): Beyond Continuity. Institutional Change in Advanced Political Economies, Oxford, 1-39.

Thelen, K. (2002): How Institutions Evolve: Insights from Comparative-Historical Analysis, in: Mahoney, J./Rueschmemeyer, D. (eds.): Comparative Historical Analysis in the Social Sciences, New York.

Thelen, K. (2004): How Institutions Evolve. The Political Economy of Skills in Germany, Britain, the United States and Japan, New York.

Whittall, M. (2005): Modell Deutschland under Pressure: The Growing Tensions between Works Councils and Trade Unions, Economic and Industrial Democracy, 26(4), 569-592. 


\section{Appendix}

Table A1: Core indicators of employment performance

\begin{tabular}{|c|c|c|c|c|c|c|}
\hline Year & \begin{tabular}{|c|} 
GDP \\
growth \\
(percentage \\
change to \\
previous \\
year) \\
\end{tabular} & \begin{tabular}{|} 
Employment \\
growth \\
(change to \\
previous \\
year) \\
\end{tabular} & $\begin{array}{c}\text { Real wage } \\
\text { growth } \\
\text { (compensation } \\
\text { per employee } \\
\text { in the private } \\
\text { sector) }\end{array}$ & $\begin{array}{c}\text { Standardized } \\
\text { Unemployment } \\
\text { rate (percentage } \\
\text { of civilian labor } \\
\text { force) } \\
\end{array}$ & \begin{tabular}{|c} 
Employment \\
rate (15 to 64 \\
years)
\end{tabular} & $\begin{array}{c}\text { Share of } \\
\text { atypical jobs } \\
\text { (with/without } \\
\text { part-time) }\end{array}$ \\
\hline 1992 & 2.2 & -1.5 & 10.3 & 6.3 & 66.2 & $13.4 / 6.0$ \\
\hline 1993 & -0.8 & -1.3 & 3.6 & 7.6 & 65.1 & $13.6 / 6.3$ \\
\hline 1994 & 2.7 & -0.1 & 2.9 & 8.2 & 64.5 & $13.6 / 6.6$ \\
\hline 1995 & 1.9 & 0.2 & 3.4 & 8.0 & 64.6 & $13.4 / 6.0$ \\
\hline 1996 & 1.0 & -0.3 & 1.0 & 8.7 & 64.3 & $14.2 / 6.4$ \\
\hline 1997 & 1.8 & -0.1 & 0.6 & 9.4 & 63.8 & $14.6 / 6.4$ \\
\hline 1998 & 2.0 & 1.2 & 0.8 & 9.1 & 64.7 & $14.5 / 6.2$ \\
\hline 1999 & 2.0 & 1.4 & 1.0 & 8.2 & 65.2 & $16.2 / 8.3$ \\
\hline 2000 & 3.2 & 1.9 & 2.0 & 7.5 & 65.6 & $16.9 / 7.9$ \\
\hline 2001 & 1.2 & 0.4 & 1.6 & 7.6 & 65.8 & $18.1 / 8.6$ \\
\hline 2002 & 0.0 & -0.6 & 1.3 & 8.4 & 65.3 & $18.3 / 8.5$ \\
\hline 2003 & -0.2 & -0.9 & 1.6 & 9.3 & 64.6 & $19.1 / 9.0$ \\
\hline 2004 & 1.2 & 0.4 & 0.1 & 9.8 & 65.0 & $19.2 / 9.5$ \\
\hline 2005 & 0.8 & -0.1 & -0.1 & 10.6 & 65.5 & $19.4 / 9.5$ \\
\hline 2006 & 3.0 & 0.6 & 1.3 & 9.9 & 67.2 & $20.9 / 10.6$ \\
\hline 2007 & 2.5 & 1.7 & 1.3 & 8.4 & 69.0 & $22.5 / 11.3$ \\
\hline 2008 & 1.3 & 1.3 & 2.4 & 7.3 & - & - \\
\hline
\end{tabular}

Sources: OECD Employment Outlook, Employment Outlook Statistics; last column: authors' calculation based on GSOEP. 